\title{
Factors associated with family risk of children with special health care needs*
}

\author{
Fatores associados ao risco familiar de crianças com necessidades especiais de saúde \\ Factores asociados con el riesgo familiar de niños con necesidades especiales de salud
}

\author{
Aline Cristiane Cavicchioli Okido ${ }^{1}$, Eliane Tatsch Neves², Giovana Natali Cavicchioli ${ }^{3}$, Leonardo Bigolin Jantsch ${ }^{2}$, \\ Fernanda Portela Pereira², Regina Aparecida Garcia Lima ${ }^{4}$
}

How to cite this article:

Okido ACC, Neves ET, Cavicchioli GN, Jantsch LB, Pereira FP, Lima RAG. Factors associated with family risk of children with special health care needs. Rev Esc Enferm USP. 2018;52:e03377. DOI: http://dx.doi.org/10.1590/S1980-220X2017048703377

* Extracted from the final work: "Famílias de crianças com necessidades especiais de saúde: avaliação do risco familiar”, Universidade de São Paulo, Escola de Enfermagem de Ribeirão Preto, 2017.

${ }^{1}$ Universidade Federal de São Carlos, Departamento de Enfermagem, São Carlos, SP, Brazil.

${ }^{2}$ Universidade Federal de Santa Maria, Departamento de Enfermagem, Santa Maria, RS, Brazil.

${ }^{3}$ Universidade de São Paulo, Escola de Enfermagem de Ribeirão Preto, Ribeirão Preto, SP, Brazil.

${ }^{4}$ Universidade de São Paulo, Escola de Enfermagem de Ribeirão Preto, Departamento de Enfermagem Materno-Infantil e Saúde Pública, Ribeirão Preto, SP, Brazil.

\begin{abstract}
Objective: To identify the factors associated with family risk of children with special health care needs. Methods: Bicentric study, with a cross-sectional design and a quantitative approach, with family caregivers of children with special health care needs. Instruments were applied to obtain a sociodemographic characterization, and identify and classify the family risk. For analysis between variables, Mann-Whitney and Fisher's exact tests were used and the Spearman's correlation coefficient was calculated. Results: One hundred and eighteen caregivers participated in the study. The average family risk score was $3.53( \pm 3.76)$, with a median of 3.0 , and minimum and maximum values of 0 and 16, respectively, with no significant difference between the two studied Brazilian municipalities. In municipality 1 , the number of siblings presented a positive correlation with the average family risk score $(0.011, p<0.05)$. Level of education and marital status of the caregiver showed a significant association with the result $(0.038$ and 0.002 , respectively). The social classification variable presented a negative correlation with the outcome in municipalities $1(0.003, p<0.01)$ and $2(0.006, p<0.01)$. Conclusion: To classify the family risk and recognize associated factors can be taken as a basis for fair home care to children with special health care needs.
\end{abstract}

\section{DESCRIPTORS}

Disabled Child; Caregivers; Family; Pediatric Nursing; Health Vulnerability. 


\section{INTRODUCTION}

The most common diagnoses of Children with Special Health Care Needs (CSHCN) involve prematurity, congenital malformations, metabolic disorders, and aftereffects of severe infections, traumas, or other diseases developed over life $^{(1)}$. However, regardless of the diagnosis, these children require complex and continuous health care, which results in the incorporation of new knowledge and practices into the routine of families ${ }^{(2)}$.

Regarding the biological dimension, CSHCN may demand various types of care, such as oxygen therapy, enteral nutrition, and a continuous medication regimen ${ }^{(3)}$, which exemplifies the individual vulnerability of this public ${ }^{(4)}$.

The routine of these families is marked by efforts and difficulties which transcend the child's clinical fragility and refer to social vulnerability, such as low income and low level of education of caregivers ${ }^{(5)}$. An investigation that examined the challenges faced by relatives who take care of CSHCN in the household environment reported that lack of financial resources to meet the minimum care demands is common ${ }^{(4)}$. Another study whose objective was to understand the hospital discharge process of CSHCN reinforces the perspective of social vulnerability by emphasizing the absence of a support network for family caregivers to manage home care ${ }^{(6)}$.

The difficulty of access to healthcare also strengthens individual and social vulnerabilities, because the healthcare network oriented to help these children is considered fragile and uncoordinated $^{(6)}$. Studies revealed that inequity in access to health services is common among CSHCN, notably for the subgroup with medical complexities ${ }^{(6-7)}$. In addition, there are socioeconomic factors that hinder the access of CSHCN and their families to health services and affect the quality of the care $\operatorname{received}^{(7)}$. In this regard, families feel helpless, in need of information and guidance so they can continue care and treatment ${ }^{(6)}$.

In face of these challenges, the present investigation assumes that Primary Health Care (PHC) can help families of CSHCN, given its potential to positively impact the health of the collectivity and people who experience individual, social, and programmatic vulnerability, through care grounded on the perspective of comprehensiveness, with the formation of bonds and the consequent guarantee of longitudinality ${ }^{(8)}$.

Nevertheless, it is necessary to know the structure and functioning of families, to suggest interventions compatible with the identified needs. Consequently, the objective of the present study was to identify factors associated with family risk of $\mathrm{CSHCN}$ in two Brazilian municipalities.

\section{METHOD}

\section{StUdy TYPE}

Bicentric study, with a cross-sectional design and a quantitative approach.

\section{SCENARIO}

The study was carried out in two Brazilian municipalities. The first municipality is located in the state of São Paulo, and the second in the state of Rio Grande do Sul.

\section{Data collection}

The empirical material used in the present study was part of the database of the "Prevalence and access of children with special health care needs in primary health care services" matrix project. This investigation had the objective of calculating the prevalence of CSHCN in the two municipalities, based on cluster sampling, using the Children with Special Health Care Needs Screener CSHCN Screener instrument, translated and adapted for Brazilian Portuguese ${ }^{(9)}$. In the matrix study, in which 407 caregivers and/or family members participated, the translated version of CSHCN Screener instrument was applied and $118 \mathrm{CSHCN}$ were identified after the analysis of the instrument domains. The same population was the sample of the present investigation. Data collection occurred from March to August 2015.

\section{INCLUSION CRITERIA}

The specific inclusion criteria for the present study were: to be a caregiver and/or a relative of a child between 0 and 12 years identified as a CSHCN in the application of the CSHCN Screener screening instrument, to be 18 years old or older, and to live in the municipalities where the investigation was carried out. Caregivers and/or relatives that ignored the clinical conditions of the child were excluded, for this was a requirement to fill in the screening instrument.

\section{INSTRUMENTS}

To produce the empirical material for the present paper, the authors analyzed the data from a questionnaire of socioeconomic characterization and an instrument of identification and classification of family risk based on the scores of the Family Risk Scale by Coelho and Savassi ${ }^{(10)}$. This scale has 13 risk sentinels, which make up a total score that is classified as risk grades: a score from 0 to 4 indicates no risk (R0), 5 or 6 points equals a low risk (R1), 7 or 8 corresponds to an intermediate risk (R2), and a score higher than 9 means maximum risk (R3). Although this instrument has not been submitted to validation processes and psychometric analysis, it is in the public domain and shows practical applicability. It is adopted by the Brazilian Ministry of Health ${ }^{(11)}$, a fact that helps justify the choice for it. It is noteworthy that the research instruments were applied in the health units by a trained team of interviewers. The average duration of the instrument application was 15 minutes.

\section{DATA ANALIYSIS AND TREATMENT}

After double typing and validation of the database organized in the Excel software, information was exported to the SPSS software, used to run statistical analyses. The dependent variable or response variable was family risk, sometimes analyzed as a numerical variable (average family risk score), sometimes taken as categorical dichotomous (no risk: 0 to 4 points; with risk: 5 to 16 points). 
Independent variables were: age, in years, of the $\mathrm{CSHCN}$ (numerical variable); skin color of the CSHCN (categorical variable); whether the $\mathrm{CSHCN}$ attend day care center or school (yes or no); number of siblings (numerical variable); Family Health Strategy (FHS) coverage (categorical variable); social classification of the family according to the Brazilian Association of Research Companies (Associação Brasileira de Empresas de Pesquisa - ABEP) (numerical variable); mother's or main caregiver's level of education (categorical variable); mother's or main caregiver's marital status (categorical variable); and main caregiver's age (numerical variable).

Categorical variables were described using absolute and relative frequency measurements, and numerical variables were treated with central tendency, variability, and position measurements. Regarding analytical statistical analyses, Fisher's exact test was applied for categorical variables, and the Mann-Whitney test was used to compare the average family risk score for the same type of variables. Spearman's correlation coefficient was calculated for numerical variables. All the tests adopted a significance level of 5\%.

\section{ETHICAL ASPECTS}

Given the participation of human subjects in the study, the ethical principles established by Resolution 466/12 of the Brazilian National Commission for Ethics in Research, of the Brazilian National Health Council, were followed. The proposal was submitted to the appreciation of the Research Ethics Committee of the Universidade Federal de Santa Maria and approved under protocol 829.522 on October 14, 2014. To ensure the integrity of the people involved in the study, a free and informed consent form was designed to instruct these people about the objectives of the investigation, the procedures to collect data, possible risks or embarrassments, benefits, and the guarantee of secrecy and respect for the desire to participate in the study or not. After reading and discussing the form with the researchers, the participants signed it and received a copy of it.

\section{RESULTS}

The study sample was 118 caregivers and/or family members of CSHCN, 68 from municipality 1 and 50 from municipality 2. Municipality 1 showed a prevalence of males in CSHCN (55.8\%), and municipality 2 had a predominance of females (52\%). The average age of CSHCN was 6.11 and 6.55 years, respectively, in municipalities 1 and 2. Concerning clinical characterization, diagnoses of disorders of the respiratory system and neurological problems (self-reported by caregivers) stood out, and the most common disease in each class was asthma and hyperactivity, respectively. The main special health care needs were drug therapy (54.2\%) and the use of health services beyond the average demand by another child from the same age group.

The results from both municipalities showed that most caregivers were the mothers of the CSHCN: 53 (77\%) in municipality 1 and 34 (68\%) in municipality 2 . The father figure was mentioned as the main caregiver by four families from municipality 2 , and municipality 1 presented no father as the person in charge of care to the CSHCN.

The average family risk score in the total examined population (municipalities 1 and 2 ) was $3.53( \pm 3.76)$, with a median of 3.0, and minimum and maximum values of 0 and 16, respectively. Most families of CSHCN ( 80 or $67.8 \%$ ) did not present any risk (R0). Among the families that presented some risk, $15(12.7 \%)$ had scores 5 or 6 and were classified as presenting low risk; 12 (10.2\%) obtained scores 7 or 8 and were categorized as presenting intermediate risk; and $11(9.3 \%)$ reached scores higher than 9 and were grouped as presenting maximum risk. Analysis of the results of each municipality revealed that the average family risk score of municipality 1 was higher than that of municipality 2 (3.98 versus 2.92), but both values indicated a null risk.

Table 1 presents the relationship between the nominal variable family risk and the categorical sociodemographic variables of the CSHCN and their caregivers.

Table 1 - Relationship between the family risk variable and the sociodemographic variables of the CSHCN and their caregivers - Ribeirão Preto, São Paulo/Santa Maria, Rio Grande do Sul, Brazil, 2015.

\begin{tabular}{|c|c|c|c|c|c|c|}
\hline \multirow{3}{*}{ Variables } & \multicolumn{3}{|c|}{ MUNICIPALITY 1} & \multicolumn{3}{|c|}{ MUNICIPALITY 2} \\
\hline & No risk & Risk & $p$ & No risk & Risk & $p$ \\
\hline & n $(\%)$ & n (\%) & & n (\%) & n $(\%)$ & \\
\hline \multicolumn{7}{|l|}{ Skin color of CSHCN } \\
\hline White & $25(62.5)$ & $15(37.5)$ & $0.924 *$ & $30(73.2)$ & $11(26.8)$ & $0.741^{*}$ \\
\hline Black & $2(50.0)$ & $2(50.0)$ & & $1(100.0)$ & $0(0.0)$ & \\
\hline Brown & $15(62.5)$ & $9(37.5)$ & & 7 (87.5) & $1(12.5)$ & \\
\hline CSHCN attends a day care center/school & & & $0.999 *$ & & & $0.686^{*}$ \\
\hline Yes & $38(62.3)$ & $23(37.7)$ & & $31(77.5)$ & $9(22.5)$ & \\
\hline No & $4(57.1)$ & $3(42.9)$ & & $7(70.0)$ & $3(30.0)$ & \\
\hline Caregiver's level of education & & & $0.038^{*}$ & & & $0.282^{*}$ \\
\hline Elementary school & $9(42.9)$ & $12(57.1)$ & & $14(63.6)$ & $8(36.4)$ & \\
\hline High school & $27(65.9)$ & $14(34.1)$ & & $15(83.3)$ & $3(16.7)$ & \\
\hline Higher education & $5(100.0)$ & $0(0.0)$ & & $8(88.9)$ & $1(11.1)$ & \\
\hline
\end{tabular}


...continuation

\begin{tabular}{|c|c|c|c|c|c|c|}
\hline \multirow{3}{*}{ Variables } & \multicolumn{3}{|c|}{ MUNICIPALITY 1} & \multicolumn{3}{|c|}{ MUNICIPALITY 2} \\
\hline & No risk & Risk & $p$ & No risk & Risk & $p$ \\
\hline & n (\%) & n (\%) & & n (\%) & n (\%) & \\
\hline Marital status & & & $0.002^{*}$ & & & $0.735^{*}$ \\
\hline Does not have a partner & $5(29.4)$ & $12(70.6)$ & & $13(72.2)$ & $5(27.8)$ & \\
\hline Has a partner & $37(72.5)$ & $14(27.5)$ & & 25 (78.1) & $7(21.9)$ & \\
\hline
\end{tabular}

*Fisher's exact test.

Table 2 shows the average family risk score according to the explanatory variable named Family Health Strategy coverage. This variable refers to the neighborhood where the families of the CSHCN live, that is, it reveals if they live in a place where the coverage of FHS is higher or lower than the average coverage in the municipality. The MannWhitney test was used to compare the average family risk scores among the categorical variables.

Table 2 - Average family risk score according to the Family Health Strategy coverage explanatory variable - Ribeirão Preto, São Paulo/ Santa Maria, Rio Grande do Sul, Brazil, 2015.

\begin{tabular}{lcccc}
\hline \multirow{2}{*}{ Variables } & \multicolumn{2}{c}{ MUNICIPALITY 1 } & \multicolumn{2}{c}{ MUNICIPALITY 2 } \\
\cline { 2 - 5 } & $\begin{array}{c}\text { Below average FHS } \\
\text { coverage }\end{array}$ & $\begin{array}{c}\text { Above average FHS } \\
\text { coverage }\end{array}$ & $\begin{array}{c}\text { Below average } \\
\text { FHS coverage }\end{array}$ & $\begin{array}{c}\text { Above average FHS } \\
\text { coverage }\end{array}$ \\
\hline $\mathrm{n}(\%)$ & $44(64.7)$ & $24(35.3)$ & $23(46)$ & $27(54)$ \\
Family risk average score & 3.66 & 4.58 & 2.83 & 3.00 \\
Standard deviation & 3.685 & 4.510 & 2.657 & 3.952 \\
Mean R & 3.00 & 3.00 & 2.00 & 2.00 \\
$P$ & & $0.508^{* *}$ & & $0.626^{* *}$ \\
\hline
\end{tabular}

**:Mann-Whitney test.

In municipality 1 , the number of siblings presented a positive correlation with the average family risk score $(0.011$, $p<0.05)$. The ages of the CSHCN and their main caregiver did not show a statistically significant correlation in neither examined municipality. The correlation between the numerical variable social classification/ABEP and the average family risk score was negative, that is, the family risk was higher in families with lower scores in municipality $1(0.003, p<0.01)$ and $2(0.006, p<0.01)$. The correlation matrix, which presents the numerical variables and outcomes, is shown in Table 3.

Table 3 - Spearman's correlation between the average family risk score and numerical variables - Ribeirão Preto, São Paulo/Santa Maria, Rio Grande do Sul, Brazil, 2015.

\begin{tabular}{lcccc}
\hline Variables & CSHCN age (months) & Caregiver's age (years) & Number of siblings & ABEP classification \\
\hline Average family risk score M1 & 0.114 & 0.151 & $0.279^{*}$ & $-0.329^{* *}$ \\
Average family risk score M2 & -0.082 & -0.132 & 0.129 & $-0.353^{* *}$ \\
\hline
\end{tabular}

*Significant correlation $(\mathrm{p}<0.05)$; **Significant correlation $(\mathrm{p}<0.01)$.

\section{DISCUSSION}

The present study identified a prevalence (52\%) of female CSHCN in municipality 2, contrary to the information reported in the Brazilian literature related to the subject ${ }^{(12)}$ and the result found in municipality 1 . Regarding caregivers, in both places mostly the mothers were responsible for the care to the CSHCN, which corroborates the conclusions of Brazilian and international investigations ${ }^{(13-14)}$.

The results showed that $32.2 \%$ of the families with CSHCN presented some family risk (minimum, intermediate, or maximum), without a significant difference between the municipalities. In contrast, other studies that applied the same scale reported a higher percentage (80\%) of families which showed no risk ${ }^{(15-16)}$. This difference can be justified by the specificity of the examined population, given that the mentioned investigations aimed to classify all the families living in a certain coverage area, and consequently were not restricted to families with $\mathrm{CSHCN}$. From this perspective, the findings of the present study are reinforced by Brazilian and international literature, which indicates that these families are more susceptible to situations of social vulnerability ${ }^{(5,7)}$.

In municipality 1 , the caregiver's level of education showed an association with family risk $(p=0.038)$. A study 
on the growth and development of economically disadvantaged children and their relationship with environmental, socioeconomic, and biological risk factors revealed that the maternal level of education has been pointed as a determining factor for this evolution ${ }^{(17)}$. American researchers analyzed social complexity risk factors in children and concluded that the main variables related to social risk refer to the caregiver, and the variable that stood out in this scenario was proficiency in English ${ }^{(18)}$, which connects with the level of education issue.

Marital status also showed an association with family risk, that is, families whose main female caregivers can rely on the support of a partner have a reduced family risk. Literature reaffirms the importance of having support from other family members to supply instrumental and emotional help ${ }^{(4,13)}$. Concerning the frequency of attendance of the $\mathrm{CSHCN}$ to daycare centers or schools, the overall response was positive $(89.7 \%$ and $80 \%$ in municipalities 1 and 2 , respectively), which disagrees with reports of discontinuity of the schooling process because of the difficulty to balance studies and long hospitalization periods ${ }^{(13)}$.

In the present study, there was no association between family risk and skin color of CSHCN. However, an international investigation aimed to evaluate the iniquity of access to healthcare services in families of $\mathrm{CSHCN}$ identified that those with a black skin color, or whose members did not have English as the first language, or who presented a lower family income had reduced access to services in comparison to other families of $\mathrm{CSHCN}^{(7)}$.

The association between family risk and families that lived in areas with a low FHS coverage did not show a statistically significant difference. From this perspective, the findings of the present investigation match those of an American study whose objective was to identify family and environmental risks of CSHCN and analyze the association that these factors had with the received home care. No significant association was found, which emphasizes the limitation of health care professionals in protecting $\mathrm{CSHCN}$ and their families from risk situations. Nevertheless, by identifying these situations, professionals can develop differentiated care strategies ${ }^{(19)}$.

The negative correlation between the numerical variable social classification/ABEP and the average family risk score corroborates the results of an international study which concluded that factors such as family income, ethnicity, maternal level of education, and geographic location of the household may be associated with the vulnerability situation $^{(20)}$. The positive correlation between the average family risk score and the number of siblings can be justified by this study, given that the number of members in the family has also been pointed out as a variable associated with vulnerability.

Although the participants of the present investigation had an income higher than the Brazilian average, with a predominance of the $\mathrm{C} 1$ class $(38.2 \%)$ - which refers to a monthly income of $\mathrm{R} \$ 2,705$ (BRL), financial problems are recurrent, because these children usually require more attention from healthcare services, thus interfering with the family financial situation for causing a higher number of days of absence of work. In addition, the medical costs of these children are two to threefold higher than those of children who have no special health needs ${ }^{(3,21)}$.

The limitation of the present study concerns its crosssectional design, which prevented identifying cause and effect relationships. This characteristic does not invalidate the results, but indicates the importance to develop new studies with a longitudinal design.

\section{CONCLUSION}

The present study revealed that the average family score of the evaluated families corresponded to R0, that is, no family risk, but $32.2 \%$ of the families with CSHCN showed some family risk (minimum, intermediate, or maximum). The variables maternal level of education and marital status presented a statistically significant association with the nominal variable family risk. The variable number of siblings had a positive correlation with the average family risk score $(0.021, p<0.05)$. The correlation between the numerical variable social classification/ $\mathrm{ABEP}$ and the average family risk score was negative $(-0.33, p<0.01)$.

The findings may be used to base the planning of home care to $\mathrm{CSHCN}$, allowing to prioritize those with a higher risk. It is fundamental to characterize and qualify families of CSHCN, as well as to recognize the factors associated with family risk. Regarding the implications of the present study, the authors recommend that FHS teams systematize home visits to families with the most vulnerable $\mathrm{CSHCN}$, to ensure equity and resolvability of actions. Special attention should be paid to the factors considered significant in the present investigation, for instance the main caregiver's level of education. However, by understanding that risks involve temporality, it is valid to stress that all families of $\mathrm{CSHCN}$ need to be visited and monitored throughout their disease trajectory.

\section{RESUMO}

Objetivo: Identificar os fatores associados ao risco familiar de crianças com necessidades especiais de saúde. Método: Estudo bicêntrico, com delineamento transversal e abordagem quantitativa com cuidadores familiares de crianças com necessidades especiais de saúde. Aplicaram-se instrumentos para caracterização sociodemográfica e identificação e classificação de risco familiar. Para análise entre as variáveis, foram utilizados o teste Exato de Fisher, Mann-Whitney e o coeficiente de correlação de Spearman. Resultados: Participaram 118 cuidadores. O escore médio de risco familiar foi 3,53 $( \pm 3,76)$, mediana 3,0, mínimo 0 e máximo 16, sem diferença expressiva entre os dois municípios brasileiros estudados. No município 1, o número de irmãos apresentou correlação positiva com o escore médio de risco familiar $(0,011, p<0,05)$. Já escolaridade e situação conjugal do cuidador apresentaram associação significativa com o desfecho (0,038 e 0,002, respectivamente). A variável classificação social apresentou correlação negativa com o desfecho nos 
municípios $1(0,003, p<0,01)$ e $2(0,006, p<0,01)$. Conclusão: Classificar o risco familiar e reconhecer os fatores associados subsidia um cuidado domiciliar equânime às crianças com necessidades especiais de saúde.

\section{DESCRITORES}

Crianças com Deficiência; Cuidadores; Família; Enfermagem Pediátrica; Vulnerabilidade em Saúde.

\section{RESUMEN}

Objetivo: Identificar los factores asociados con el riesgo familiar de niños con necesidades especiales de salud. Método: Estudio bicéntrico, con corte transversal y abordaje cuantitativo con cuidadores familiares de niños con necesidades especiales de salud. Se aplicaron instrumentos para caracterización sociodemográfica e identificación y clasificación de riesgo familiar. Para análisis entre las variables, se utilizaron la prueba Exacta de Fisher, Mann-Whitney y el coeficiente de correlación de Spearman. Resultados: Participaron 118 cuidadores. El score medio de riesgo familiar fue 3,53 $( \pm 3,76)$, mediana 3,0, mínimo 0 y máximo 16, sin diferencia expresiva entre los dos municipios brasileños estudiados. En el municipio 1, el número de hermanos presentó correlación positiva con el score medio de riesgo familiar $(0,011, p<0,05)$. Ahora bien, la escolaridad y la situación conyugal del cuidador presentaron asociación significativa con el resultado $(0,038$ y 0,002 , respectivamente). La variable clasificación social presentó correlación negativa con el resultado en los municipios $1(0,003, p<0,01)$ y $2(0,006, p<0,01)$. Conclusión: Clasificar el riesgo familiar y reconocer los factores asociados subsidia un cuidado domiciliario ecuánime a los niños con necesidades especiales de salud.

\section{DESCRIPTORES}

Niños con Discapacidad; Cuidadores; Familia; Enfermería Pediátrica; Vulnerabilidad en Salud.

\section{REFERENCES}

1. Elias ER, Murphy NA. Home care of children and youth with complex health care needs and technology dependencies. Pediatrics. 2012;129(5):996-1005. DOI: www.pediatrics.org/cgi/doi/10.1542/peds.2012-0606

2. Okido ACC, Zago MMF, Lima RAG. Care for technology dependent children and their relationship with the health care systems. Rev Latino Am Enfermagem [Internet]. 2015 [cited 2017 June 24];23(2):291-8. Available from: http://www.scielo.br/scielo.php?script=sci_ar ttext\&pid=S0104-11692015000200015

3. Okido ACC, Teles SC, Neves ET, Dupas G, Lima RAG. Technology-dependent children and the demand for pharmaceutical care. Rev Bras Enferm [Internet]. 2016 [cited 2017 Oct 25];69(4):671-8. Available from: http://www.scielo.br/scielo.php?script=sci_artte $\mathrm{xt} \& \mathrm{pid}=\mathrm{S} 0034-71672016000400718$

4. Neves ET, Cabral IE, Silveira A. Family network of children with special health needs: implications for nursing. Rev Latino Am Enfermagem [Internet]. 2013 [cited 2017 Nov 15];21(2):562-70. Available from: http://www.scielo.br/scielo.php?script=sci_arttext\&pid $=$ S0104-11692013000200562

5. Silveira A, Neves ET. Vulnerabilidade das crianças com necessidades especiais de saúde: implicações para a enfermagem. Rev Gaúcha Enferm [Internet]. 2012 [citado 2017 out. 20];33(4):172-80. Disponível em: http://www.scielo.br/scielo.php?script=sci_artte xt\&pid=S1983-14472012000400022

6. Garcia BGF, Cabral IE. Discourses on discharge care for children with special healthcare needs. Rev Bras Enferm [Internet]. 2017 [cited 2017 Oct 20];70(1):154-61. Available from: http://www.scielo.br/pdf/reben/v70n1/en_0034-7167-reben-70-01-0163.pdf

7. Kuo DZ, Goudie A, Cohen E, Houtrow A, Agrawal R, Carle AC, et al. Inequities in health care needs for children with medical complexity. Health Aff [Internet]. 2014 [cited 2017 Jun 19];33(12): 2190-8. Available from: https://www.ncbi.nlm.nih.gov/pmc/articles/ PMC4334319/

8. Silva RMM, Toso BRGO, Neves ET, Nassar PO, Zilly A, Viera CS. Resolutividade na atenção à criança com necessidade especiais de saúde. Rev Pesq Qual [Internet]. 2017 [citado 2017 jun. 24];5(7):23-37. Disponível em: http://rpq.revista.sepq.org.br/index.php/ rpq/article/view/50/61

9. Arrué AM, Neves ET, Magnago TSBS, Cabral IE, Gama SGN, Hökerberg YHM. Tradução e adaptação do Children with Special Health Care Needs Screener para o português do Brasil. Cad Saúde Pública [Internet]. 2016 [citado 2018 mar. 12];32(6):e00130215. Disponível em: http://www.scielo.br/pdf/csp/v32n6/1678-4464-csp-32-06-e00130215.pdf

10. Coelho FLG, Savassi LCM. Aplicação de Escala de Risco Familiar como instrumento de priorização das Visitas Domiciliares. Rev Bras Med Fam Comunidade [Internet]. 2004 [citado 2017 jul. 14];1(2):19-26. Disponível em: https://rbmfc.org.br/rbmfc/article/view/104/98

11. Brasil. Ministério da Saúde; Secretaria de Atenção à Saúde, Departamento de Atenção Básica. Melhor em Casa: a segurança do hospital no conforto do seu lar. Brasília; 2013 (Caderno de Atenção Domiciliar, v.1).

12. Okido ACC, Pina JC, Lima RAG. Factors associated with involuntary hospital admissions in technology-dependent children. Rev Esc Enferm USP [Internet]. 2016 [cited 2017 June 15];50(1):29-35. Available from: http://www.scielo.br/scielo.php?pid=S008062342016000100029\&script=sci_arttext

13. Cabral IE, Moraes JR. Family caregivers articulating the social network of a child with special health care needs. Rev Bras Enferm [Internet]. 2015 [cited 2017 Oct 02];68(6):1078-85. Available from: http://www.scielo.br/pdf/reben/v68n6/en_0034-7167reben-68-06-1078.pdf

14. Dillon-Wallace JA, McDonagh SH, Fordham LA. Maternal employment, work experiences, and financial well-being of Australian mothers who care for young children with special health care needs. J Fam Issues. 2014;37(3):299-320. DOI: https://doi. org/10.1177/0192513X14561522

15. Souza EC, Santana CP, Cavalcante PS, Bortoletto MS, Mathias TAF. Classificação de famílias segundo situações de risco. Cogitare Enferm [Internet]. 2013 [citado 2017 jan 23];18(1): 50-6. Disponível em: https://revistas.ufpr.br/cogitare/article/view/31302 
16. Rego AD, Oliveira RG, Macerau WM, Mathias TAF, Molena-Fernandes CA, Radovanovic CA. Estratificação de risco familiar no contexto da Estratégia de Saúde da Família. Rev Enferm UFPE On line [Internet]. 2016 [citado 2017 jun. 14];10(3):977-84. Disponível em: https://periodicos.ufpe.br/revistas/revistaenfermagem/article/view/11048/12457

17. Neves KD, Morais RL, Teixeira RA, Pinto PA. Growth and development and their environmental and biological determinants. J Pediatr (Rio J) [Internet]. 2016 [cited 2017 Oct 15];92(3):241-50. Available from: http://www.scielo.br/pdf/jped/v92n3/pt_0021-7557jped-92-03-0241.pdf

18. Schrager SM, Arthur KC, Nelson J, Edwards AR, Murphy JM, Mangione-Smith R, et al. Development and validation of a method to identify children with social complexity risk factors. Pediatrics. 2016;138(3):e20153787. DOI: https://doi.org/10.1542/peds.2015-3787

19. Brandy JB, Caprice B, Melissa K, Hinojosa M. Factors associated with having a medical home for children at-risk of experiencing negative events : results from a national study. Matern Child Health J. 2015;19(10):2233-42.DOI https://doi.org/10.1007/s10995-015$1742-\mathrm{x}$

20. Lykens KA, Fulda KG, Bae S, Singh KP. Differences in risk factors for children with special health care needs (CSHCN) receiving needed specialty care by socioeconomic status. BMC Pediatr [Internet]. 2009 [cited 2017 July 26];9:48. Available from: https://www.ncbi.nlm.nih.gov/pmc/articles/PMC2729735/

21. Looman WS, Presler E, Erickson MM, Garwick AE, Cady RG, Kelly AM. Care coordination for children with complex special health care needs: the value of the advanced practice nurse's enhanced scope of knowledge and practice. J Pediatr Health Care [Internet]. 2013 [cited 2017 July 26];27(4):293-303. Available from: https:/www.ncbi.nlm.nih.gov/pmc/articles/PMC3433641/

\section{Financial support}

Conselho Nacional de Desenvolvimento Científico e Tecnológico (CNPq). Universal public notice, process no. 459081/2014-4. 